\title{
Seasonal stratification and property distributions in a tropical estuary (Cochin estuary, west coast, India)
}

\author{
A. Shivaprasad, J. Vinita, C. Revichandran, P. D. Reny, M. P. Deepak, K. R. Muraleedharan, and K. R. Naveen Kumar \\ National Institute of Oceanography, Regional Centre, Dr. Salim Ali road, Kochi-18, Kerala, India
}

Correspondence to: A. Shivaprasad (shivaprasadnio@gmail.com)

Received: 4 July 2012 - Published in Hydrol. Earth Syst. Sci. Discuss.: 27 July 2012

Revised: 11 December 2012 - Accepted: 11 December 2012 - Published: 21 January 2013

\begin{abstract}
The intratidal, spring-neap and seasonal variations in stratification were examined in the Cochin estuary. The observations established a strong connection with the distribution of chemical and biological properties. The influence of tides and river discharge forcing in water column stability was quantified using potential energy anomaly (PEA) and stratification parameter. Partially mixed (neap) and wellmixed (spring) conditions during low river discharge (dry) period were altered in monsoon by the salt wedge intrusions. The ecological impact of salt wedge propagation on high tides bringing upwelled water to the system was evident from the bottom hypoxic, high chlorophyll $a$ and nutrientrich conditions. Phosphate and nitrite concentrations were higher at the bottom saline conditions but silicate and nitrate were clearly supplied by river water. However, during ebb tide this front was driven out of the estuary. The periodic advance and retreat of the salt wedge was inevitable in making the system immune from extended hypoxia/anoxia and maintaining the health of the Cochin estuary. For the seasonally varying river flow in the estuary, salt intrusion receded with increasing river flow in monsoon and rebounded with decreasing river flow in dry season. During monsoon, the intense flushing and reduction in salinity field expansion seemed to be responsible for the limited chlorophyll $a$ levels along the surface of the Cochin estuary.
\end{abstract}

\section{Introduction}

The key to understanding stratification and de-stratification processes in different time scales (intra-tidal, spring-neap, seasonal) has gained the most attention during the last decades due to its tremendous relevance to the estuarine ecosystem. Estuaries can be classified into three types based on their longitudinal salinity distribution: partially mixed, vertically homogeneous or well-mixed, and highly stratified or salt wedge type (Dyer, 1973). The type of the estuary essentially depends on the river discharge and tidal regime, which have pronounced effects on the distributions of several physical, chemical, and biotic processes within the estuary. The differential advection of salinity creates stratification, which in turn inhibits vertical mixing of momentum. With the increase in turbulent energy, stratification is reduced by mixing directly and indirectly by reduced shear (Nepf and Geyer, 1996). Stratification diminishes vertical fluxes of ecologically important variables (Uncles et al., 1990) like heat, salt, oxygen and nutrients. Physical dynamics play a critical role in estuarine biological production, material transport and water quality (Kasai et al., 2010).

The Cochin estuary is the largest among many extensive estuarine systems along the southwest coast of India. It has been identified as one of the most productive estuarine systems along the west coast of India by Menon et al. (2000). However, due to anthropogenic interventions, the Cochin estuary has been reported to be on the brink of an ecological disaster by Dinesh Kumar et al. (1994). Further, the sediment heavy metal contamination of this estuary has placed the region among the impacted estuaries in the world (Balachandran et al., 2005). The runoff components like municipal waste discharge from the surrounding city and riverine water carrying industrial and agricultural wastes are responsible for nutrient enrichment influencing the estuarine water quality (Joseph and Ouseph, 2010).

Numerous studies reveal the dynamics of the energetic environment of the Cochin estuary. Tides in the Cochin estuary are of mixed semidiurnal type with an average tidal range 
of $1 \mathrm{~m}$ (Qasim and Gopinathan, 1969). According to Srinivas et al. (2003b), the relative importance of the semidiurnal and the diurnal components keeps changing throughout the month. Spring phase is dominated by semidiurnal tides and neap phase by diurnal tides. There is a rapid decay in the amplitudes of the principal tidal constituents as they propagate upstream. However, tidal amplification has been observed in the south estuary during pre-monsoon season (March), which is possibly caused by the closure of the hydraulic barrier at Thanneermukkom (upstream) (Balachandran et al., 2008). In the Cochin estuary, currents are dominated by tidal signals; semidiurnal tidal regimes experience swifter tidal currents than diurnal tidal regimes (Srinivas et al., 2003a). Balachandran et al. (2008), with the help of a model, showed that strong currents prevail at the central estuary (from Cochin inlet to $22 \mathrm{~km}$ south) whereas weak and slow currents are found in the north and south estuary. The strong ebb velocity of about $130 \mathrm{~cm} \mathrm{~s}^{-1}$ at the Cochin inlet (Udaya Varma et al., 1981), which is comprised in the central estuary, maintains an effective flushing through the channel in this region (Balachandran et al., 2008).

For an ecological study, an interdisciplinary approach linking the physical phenomena with chemical and biological properties is essential, and for the Cochin estuary this study is first of its kind.The physical processes (stratification, horizontal and vertical advection, flushing, etc.) that govern the ecological parameters have not been rigorously investigated in the region to date. For the efficient implementation of estuarine management plans, an imperative study of the impact of stratified systems on water quality and ecosystem ecology is essential. The objective of the present study is to assess (1) the intratidal and spring-neap variations in stratification of water column in dry and wet seasons, and (2) the horizontal extent of salt intrusion and the relation between salinity and property distributions.

\subsection{Geomorphology}

The Cochin estuary is the largest among many extensive estuarine systems along the southwest coast of India. It extends from Munambam $\left(10^{\circ} 10^{\prime} \mathrm{N}, 76^{\circ} 15^{\prime} \mathrm{E}\right)$ in the north, to Thanneermukkom $\left(09^{\circ} 30^{\prime} \mathrm{N}, 76^{\circ} 25^{\prime} \mathrm{E}\right)$ in the south over a length of $\sim 80 \mathrm{~km}$ (Fig. 1). The system is characterised by its long axis lying parallel to the coastline, with several small islands and interconnected waterways, and it covers an area of about $300 \mathrm{~km}^{2}$. The width of this estuarine system varies from $450 \mathrm{~m}$ to $4 \mathrm{~km}$, and the depths range from $15 \mathrm{~m}$ at the Cochin inlet to $3 \mathrm{~m}$ near the head with an average depth of $2.5 \mathrm{~m}$ (depths are reduced to chart datum). The estuary is separated from the sea by barrier spits interrupted by tidal inlets at Munambam and Cochin. The openings at Cochin, known as the Cochin inlet, with a width of $450 \mathrm{~m}$, and another at Munambam, provide perennial connections to the Arabian Sea. The Cochin Port, situated on the Willington Island, is near the Cochin inlet, which provides the

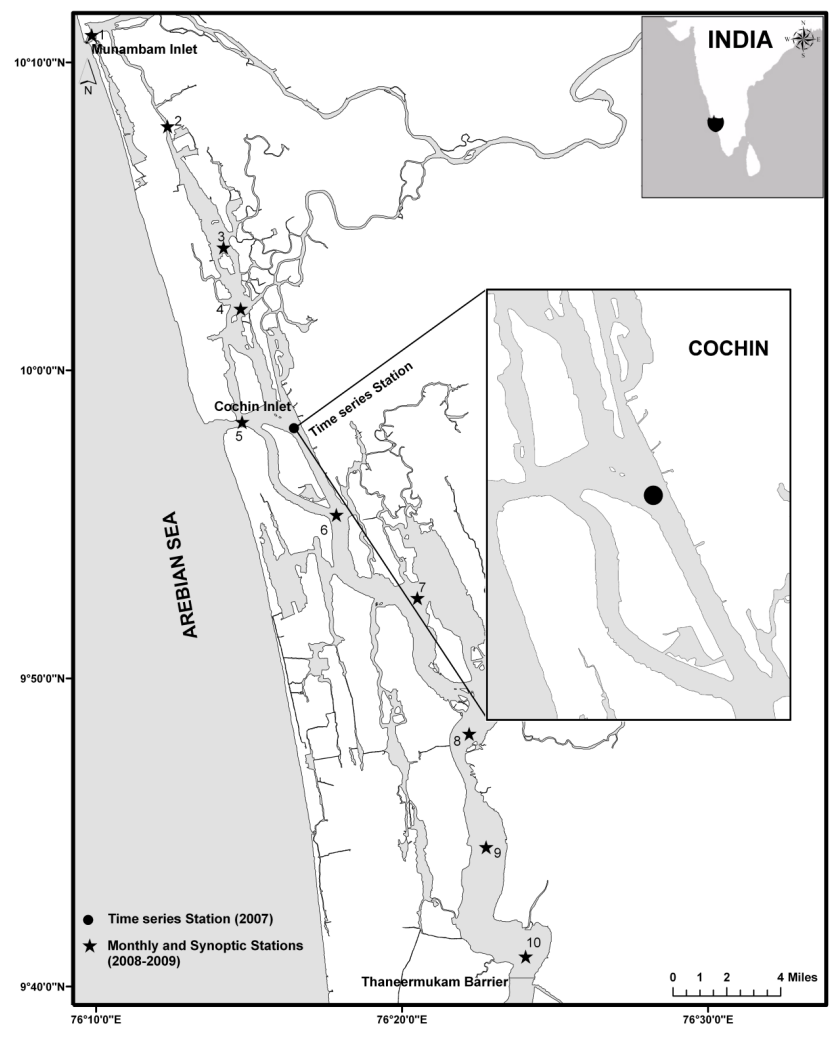

Fig. 1. The Cochin estuary (West coast, India), showing stations and extent of backwaters, having two inlets to Arabian Sea Munambam (north) and Cochin inlet (middle of the extent of backwaters). The time series station which is located $5 \mathrm{~km}$ way from Cochin inlet. Synoptic and monthly stations are discerningly marked in the backwaters.

main entrance channel to this harbour. The rivers that discharge freshwater into this estuarine system are Periyar in the north; Pampa, Achankovil, Manimala, and Meenachil in the south; and Muvattupuzha, midway between the two (Srinivas et al., 2003a). Munambam inlet is located further north, through which $70 \%$ of the Periyar River discharges into the Arabian Sea and the rest through the Cochin inlet (unpublished data). The Thannermukkom barrier in the south was made functional in 1976 to prevent saltwater incursion and to promote cultivation in the low-lying fields. It remains closed from January to May every year.

\subsection{Climatological setting}

The domain experiences humid equatorial tropic climate with the mean daily temperatures ranging from $19.8^{\circ} \mathrm{C}$ to $36.7^{\circ} \mathrm{C}$. Mean annual temperature ranges from $25.0-27.5^{\circ} \mathrm{C}$ in the coastal lowlands (Government of Kerala, General features, 2005b; Brenkert and Malone, 2003). The average monthly rainfall for the years 1978 to 2002 at the different physiographic zones of the river basin is shown in Fig. 2a. In most years, pre-monsoon (March-May) experiences the 


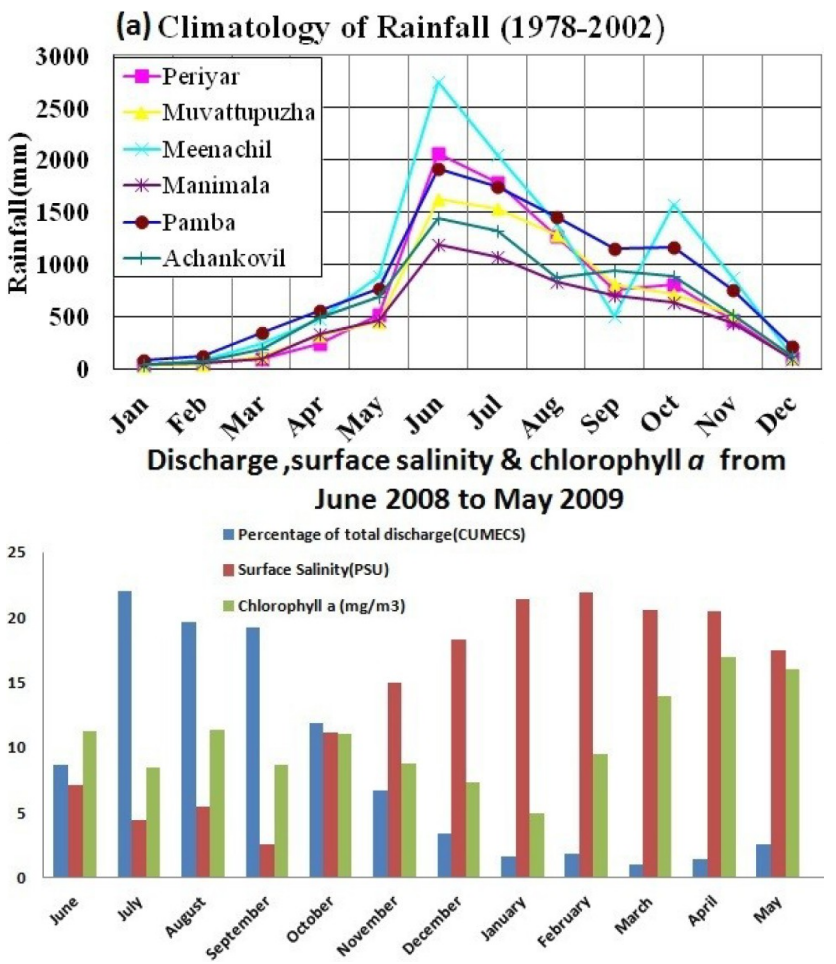

Fig. 2. (a) Climatology of rainfall (1978-2002) in the catchment of Cochin backwaters; (b) Monthly river discharge, surface salinity, surface chlorophyll $a$ starting from June 2008 and finishing May 2009.

lowest recorded rainfall with a combined average of only $386 \mathrm{~mm} \mathrm{month}^{-1}$, thus defining the peak of the "dry" season. In contrast, southwest monsoon (June-September) receives the most rainfall with an average and maximum of $1400 \mathrm{~mm} \mathrm{month}^{-1}$ and $1891 \mathrm{~mm} \mathrm{month}^{-1}$, respectively, thus defining the peak of the "wet" season (Krishnakumar et al., 2009). The freshwater runoff data (Fig. 2b) for the year 2008 to 2009 was obtained from the Central Water Commission. About $60 \%$ to $70 \%$ of the total discharge occurred during June-September and the least $(6.82 \%)$ occurred during December-February.

\section{Materials and methods of observation}

Intensive series of hydrographic surveys comprising three different time scales of observations were carried out in the Cochin estuary: (a) time-series at a single station positioned close to the main inlet of the system (temporal study of water column stability), (b) synoptic (salt intrusion measurement), and (c) monthly observations (correlation analysis of environmental parameters) at ten stations.

\subsection{Time series observations}

Time series data were collected from a station $5 \mathrm{~km}$ upstream of the Cochin inlet during four surveys in 2007 (Fig. 1). Since the environmental behaviour and dynamics of the Cochin estuarine system is highly influenced by monsoonal rainfall and the associated runoff, we had ideally chosen both extreme conditions of seasons for data collection: pre-monsoon (dry) and monsoon (wet) seasons. Significantly, the observational coverage included two spring (2-3 May, 16-17 July 2007) and two neap (25-26 April, 24-25 July 2007) tidal phases. The measurements were done for dry (April, May) and wet (July) seasons for $30 \mathrm{~h}$ and $27 \mathrm{~h}$, respectively, covering two consecutive semidiurnal cycles. A SBE Seabird 19 plus CTD was used for recording temperature (accuracy $\pm 0.001^{\circ} \mathrm{C}$ ) and salinity (conductivity $\pm 0.001 \mathrm{Sm}^{-1}$ ) profiles with a bin size $0.2 \mathrm{~m}$ for every $30 \mathrm{~min}$ interval. The water level measurements throughout the observations were collected using tide pole and it was cross-checked with the tide table (Published by Survey of India) and the tide predicted using TASK-2000 software (POL/PSMSL Tidal Analysis Software Kit 2000, Proudman Oceanographic Laboratory, UK). Water samples collected from surface, mid-depth $(\sim 4 \mathrm{~m})$ and close to bottom at $3 \mathrm{~h}$ intervals were utilised to determine the nutrient and chlorophyll $a$ concentrations.

As a convenient measure of water column stability, potential energy anomaly (PEA, $\varphi$ ) was calculated for the entire water column for each CTD profile using the equation

$\varphi=\frac{1}{h} \int_{-h}^{0}(\bar{\rho}-\rho) g z \mathrm{~d} z$ where $\bar{\rho}=\frac{1}{h} \int_{-h}^{0} \rho \mathrm{d} z$.

Here, $g$ is gravitational acceleration $\left(\mathrm{ms}^{-2}\right), \rho$ is water density $\left(\mathrm{kg} \mathrm{m}^{-3}\right), h$ is water depth $(\mathrm{m})$ and $z$ is depth interval (m).

Simpson (1981) defined PEA as shown in equation above as the amount of mechanical energy (per $\mathrm{m}^{3}$ ) required to instantaneously homogenize the water column completely. Thereafter, this method has proved crucial for quantifying the mixing efficiency in numerous stratification studies in coastal seas and estuaries (Nunes Vaz et al., 1989; Rippeth and Simpson, 1996; Lund-Hansen et al., 1996; Ranasinghe and Pattiaratchi, 1999). Although the meteorological phenomena like wind are possible sources of mixing energy, they are overshadowed by the constancy of tidal action (Blanton, 1969) and are therefore not treated in this study.

Water column stratification for each profile in time series observation was assessed using the stratification parameter $n_{\mathrm{s}}$ defined as

$n_{\mathrm{s}}=\frac{\delta S}{\mathrm{~s}_{\mathrm{m}}}$

where $\delta S=S_{\text {bott }}-S_{\text {surf }}, S_{\text {m }}^{\prime}=1 / 2\left(S_{\text {bott }}+S_{\text {surf }}\right)$, with $S_{\text {surf }}$ and $S_{\text {bott }}$ the salinity at the surface and bottom of the water 
column, respectively. In case $n_{\mathrm{s}}<0.1$, then the water column is well mixed, when $0.1<n_{\mathrm{S}}<1.0$ then partial mixing occurs, while if $n_{\mathrm{s}}>1.0$ stratification with the presence of salt wedge is evident (Haralambidou et al., 2010).

\subsection{Synoptic observations}

The results of the time series measurements conducted in the most dynamical zone of the Cochin estuary (Balachandran et al., 2008) inspired us to proceed our observations further along the estuary to explore the longitudinal salinity dynamics. Hence, salinity intrusion surveys were undertaken from June 2008 to May 2009 during spring and neap tidal phases of each month by casting CTD-SBE $9^{11}$ plus every $8 \mathrm{~km}$ intervals from northern arm to southern arm using a speedboat $\left(40 \mathrm{~km} \mathrm{~h}^{-1}\right)$ covering ten stations along the estuary (Fig. 1). Morphology, tides and discharge were the deciding factors for the selection of sampling stations. Extensive data were gathered from stations 1 and 5, 6, 7 located at the proximity of northern and Cochin inlets, respectively; stations 2, 3, 4 at the middle of northern arm and 8, 9, 10 comprising the southern arm. Occasionally, we had to face technical problems such that the measurements obtained with CTD did not reach bottom due to strong water currents in January and also missing data of station 10 in June measurements.

The flushing time, defined as the time taken to replace the existing freshwater in the estuary at a rate equal to river discharge (Dyer, 1997), was calculated by the freshwater fraction method (Ketchum, 1983),

i.e. $T=F / Q$,

where $F$ is the total volume of the freshwater in Cochin estuary and $Q$ is the river discharge from the year 2008 to 2009 .

\subsection{Monthly observations}

In order to relate the physical forcing (tide and river discharge) to chemical and biological property distributions, additional surveys were conducted at the middle of every month from June 2008 to May 2009 (similar to the period of synoptic survey). CTD-SBE $9^{11}$ plus was used to measure temperature and salinity. Nutrients, chlorophyll $a$ and dissolved oxygen (DO) concentrations were determined from the bottle samples collected from the surface.

\subsection{Chemical and biological parameters measurements}

For the analysis of chlorophyll $a$, one litre of water sample from each depth was filtered through Whatmann GF/F filter and measured according to Strickland and Parsons (1972) using flourometer (Turner designs Instruments, Trilogy, USA). Pheophytin (acidified 0.1N HCL) concentrations were determined and deducted. Dissolved oxygen was analyzed by the Winkler's titrimeteric method. Dissolved inorganic nutrients such as nitrite $\left(\mathrm{NO}_{2}\right)$, nitrate (NO3), phosphate $\left(\mathrm{PO}_{4}^{3}\right)$ and silicate $\left(\mathrm{SiO}_{4}^{4}\right)$ were estimated following standard colorimetric techniques (Grasshoff et al., 1983).

\subsection{Statistical data analysis}

The Pearson correlation coefficients were calculated using SPSS 17 statistical software to determine the linear relationship of salinity with all chemical and biological parameters. Two-way ANOVA was carried out on the monthly surface discrete samples to examine the difference in water quality variables among the along-estuary sampling stations (spatial) or through the different sampling months (temporal), with factors of interest being season, discharge and tidal activity.

\section{Results}

\subsection{Temporal variations at single station}

\subsubsection{Tidal characteristics}

Figures $3 a-d$ give the water level and predicted tide of spring and neap phases during the observation period. The maximum range of the spring tide was $1 \mathrm{~m}$ while the neap tides did not exceed $0.59 \mathrm{~m}$. The diurnal tidal inequality was quite evident in all observations; it was prominent in dry neap with $0.20 \mathrm{~m}$ (Fig. 3a). Unlike all other tidal observations which were semidiurnal in nature, the neap tide of wet season was diurnal (Fig. 3d).

\subsubsection{Temperature}

The vertical distribution of temperature is as shown in Figs. 4-7. A pronounced surface to bottom difference in temperature was absent during spring and neap tidal phases in dry season. Even though, during the period when solar forcing during late afternoon was at its peak created a vertical difference of $\sim 1.5^{\circ} \mathrm{C}$ (Figs. 4b, 5b). However, the high tides of both the tidal phases of monsoon season experienced typically substantially lower temperature $\left(\sim 24.5^{\circ} \mathrm{C}\right)$ (Figs. 6b, 7b) at the bottom layers when compared with surface temperature $\left(\sim 27.5^{\circ} \mathrm{C}\right)$.

\subsubsection{Salinity}

The seasonally varying river flow and the tidal rhythm affected the vertical distribution of salinity is shown in Figs. 4 7. During the period April-May, low freshwater discharge (Figs. 4a, 5a) caused weaker salinity stratification (difference between the surface and near bottom salinities) relative to summer monsoon. In dry neap (April), the stratification was observed during flood with maximum of 16.35 . With the arrival of ebb phase of the first tidal cycle, stratification declined to a remarkably low value of 0.19. Again, it increased with the upcoming flood tide. During spring phase of dry season (May), stratification of the entire water column over the 

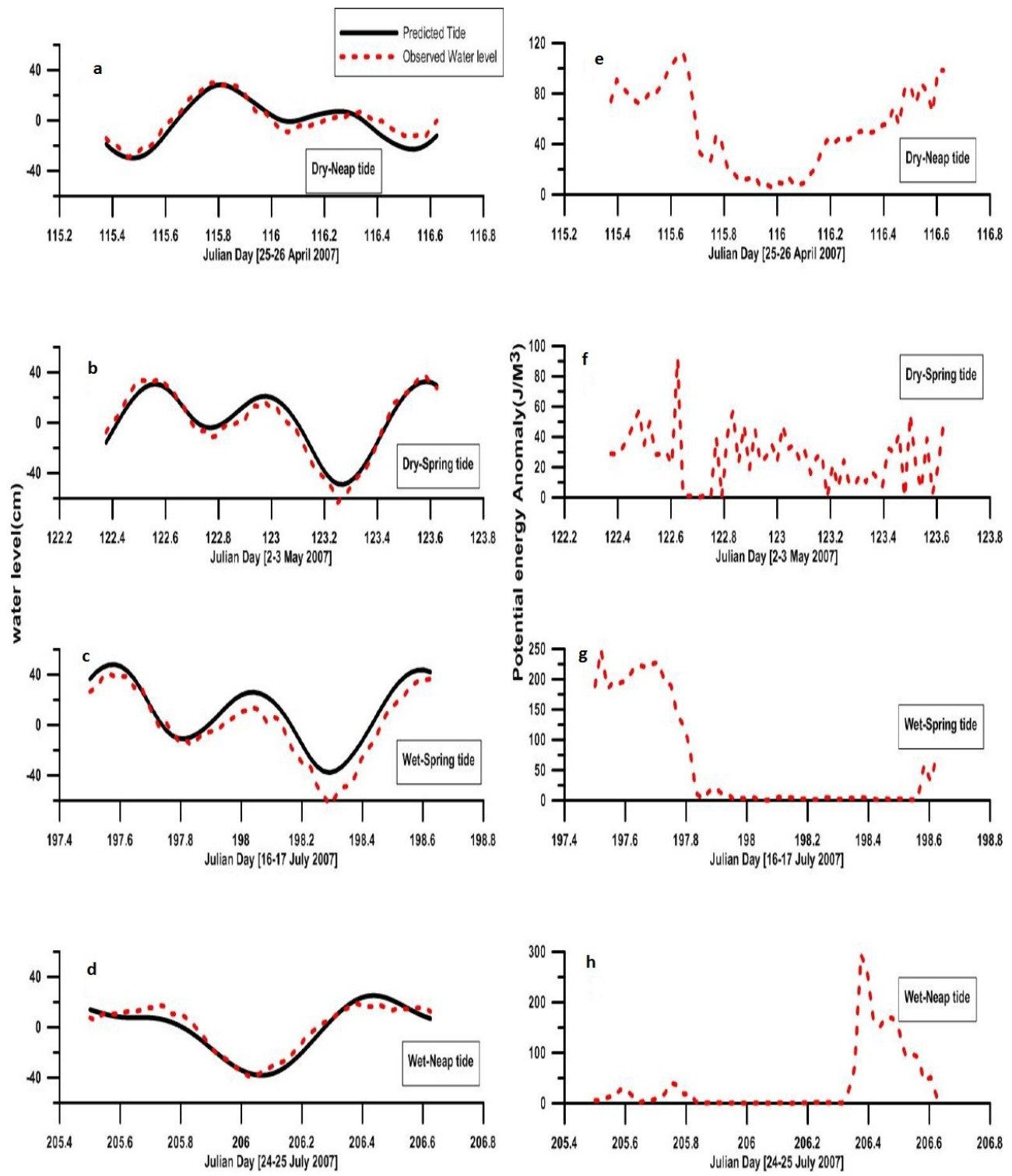

Fig. 3. (a-d) Semidiurnal variations of observed water level and predicted tide at the location; (e-f) Time series of potential energy anomaly $(\varphi)\left(\mathrm{J} \mathrm{m}^{-3}\right)$ computed from the 30 min density profiles (a, e) 25 April 09:00 LT to 26 April 15:00 LT (neap-dry); (b, f) 2 May 09:00 LT to 3 May 15:00 LT (spring-dry); (c, g) 16 July 12:00 LT to 17 July 15:00 LT (spring-wet); (d, h) 24 July 12:00 LT to 25 July 15:00 LT (neap-wet).

tidal cycles was less and the depth-averaged salinity ranged from 31.64 to 32.09 . The stratification was higher in flood (12.5) than in ebb (0.15) either due to differential advection of salinity or vertical mixing. On the other hand, during both tidal phases of monsoon (Figs. 6a, 7a), large quantities of freshwater entered the estuary, resulting in very low saline water at the surface and denser water at the bottom. Evolution of salinity stratification in water column (spring 33.24; neap 33.03 ) is associated with advection of salt wedge. The isopycnals were evenly spaced and flattened during highest high water (HHW). Notably, the entire station was flushed with freshwater of salinity $\sim 0.05$ during low tides and lowest high water (LHW). The pycnocline became unstable during ebb and the saline wedge disappeared.

\subsubsection{Stability factor and Stratification parameter}

The pattern of distribution of observed water column stability (Figs. 3e-h) corresponded well with the salinity distribution, notwithstanding seasons and tidal cycles. The springneap cycles of stabilization and destabilization of water column were prominent, which have relative importance as far as tidal estuaries are concerned. During dry season, the average PEA value computed from all density profiles was $52.02 \mathrm{~J} \mathrm{~m}^{-3}$ in neap, which almost reduced to $25.9 \mathrm{~J} \mathrm{~m}^{-3}$ 

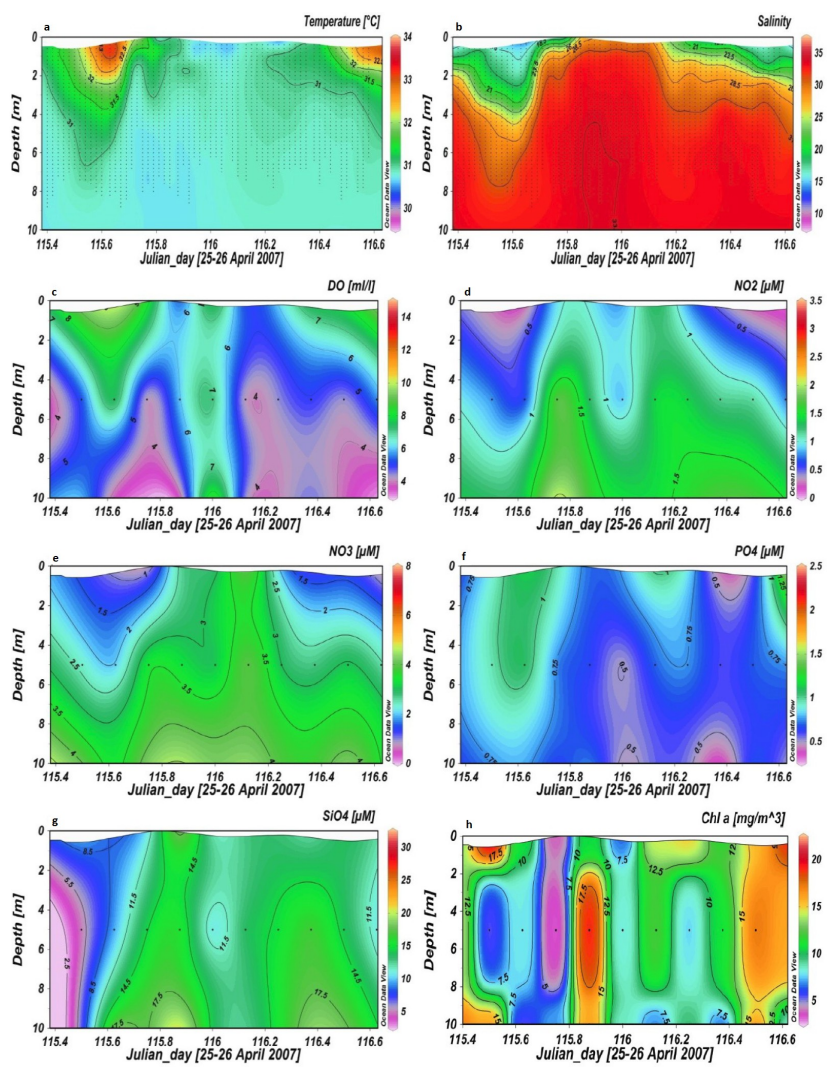

Fig. 4. Depth-time contours of salinity, temperature DO, chlorophyll $a, \mathrm{NO}_{2}, \mathrm{NO}_{3}, \mathrm{PO}_{4}^{3}, \mathrm{SiO}_{4}^{4}$ for every three hours from surface, mid-depth and bottom during neap tides of dry season.

during spring phase. This implies that the average energy required to mix the water column was about two-fold higher in neap than spring phase. It should also be noted that during dry neap, the minimum PEA value of $5.0 \mathrm{~J} \mathrm{~m}^{-3}$ was obtained during the ebb period. However, during dry spring the PEA values neared to zero for many of the density profiles over the tidal cycle. During wet, the highest values of PEA $\left(>200 \mathrm{~J} \mathrm{~m}^{-3}\right)$ in spring and neap phases indicated stratification evolved due to the advancement of the salt wedge. However, for spring, on the arrival of ebb phase, PEA values gradually declined corresponding to the retreat of salt wedge and went as low as $<1 \mathrm{~J} \mathrm{~m}^{-3}$, this low value sustained until the next tidal cycle and again the stratification began to develop at HHW. For wet neap, the water level was diurnal in nature. The observations of neap began with low PEA values $\left(\sim 10 \mathrm{~J} \mathrm{~m}^{-3}\right)$ and the advancement of salt wedge occurred at the flood phase of the tidal cycle. Again, it began to retreat during ebb. The computed PEA from the density profiles of spring phase of intrusion survey (Synoptic observation - Sect. 2.2) for the months July 2008, August 2008, November 2008 and March 2009 are shown in (Fig. 9). These months are characterised by southwest monsoon, northeast monsoon and dry period, respectively. The spatial variations
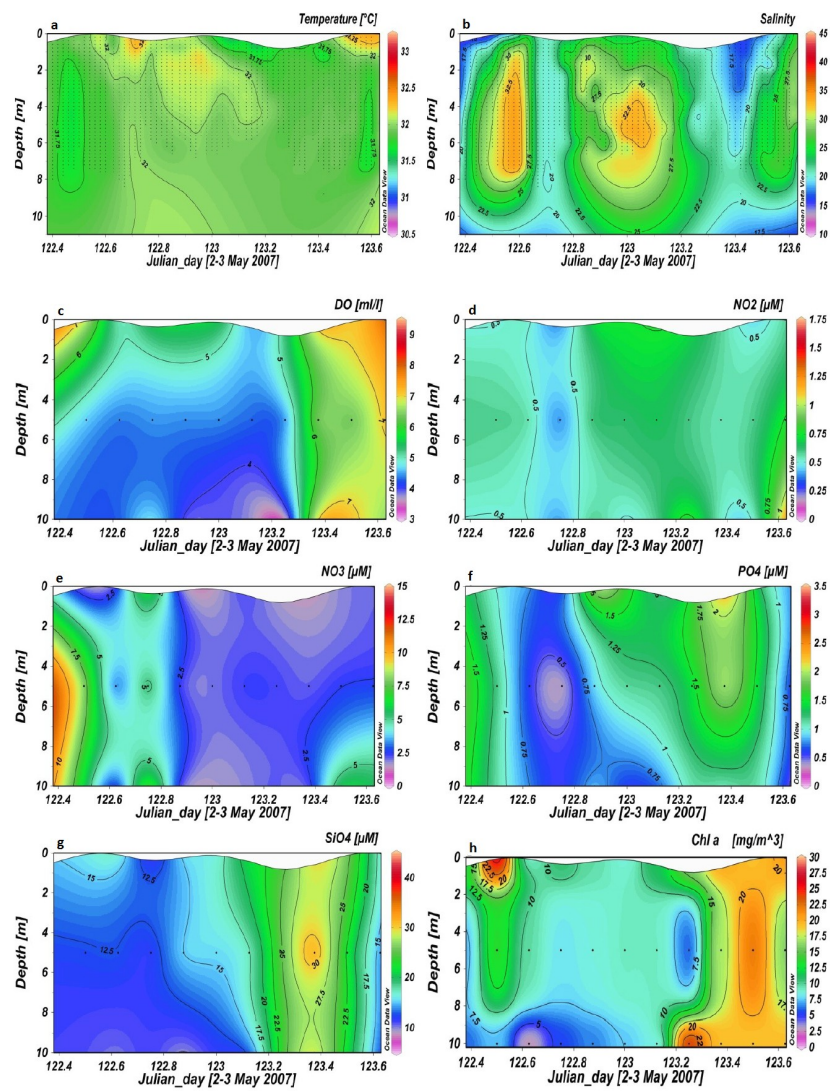

Fig. 5. Depth-time contours of salinity, temperature, DO, chlorophyll $a, \mathrm{NO}_{2}, \mathrm{NO}_{3}, \mathrm{PO}_{4}^{3}, \mathrm{SiO}_{4}^{4}$ for every three hours from surface, mid-depth and bottom during spring tide of dry season.

in PEA plainly depict the changes in stratification due to bathymetry and seasonal river discharge. During July, the PEA also reached the maximum value of $128.3 \mathrm{~J} \mathrm{~m}^{-3}$ near the inlets whereas all the other stations remained well mixed (PEA 0). In August also, similar character was observed with high values of PEA $113.2 \mathrm{~J} \mathrm{~m}^{-3}$ near the inlets. Then river discharge was reduced to $3.34 \%$ in November. This resulted in the longitudinal dispersion of the salinity field and the PEA in the upstream of the system increased to $68.2 \mathrm{~J} \mathrm{~m}^{-3}$. Later during the dry period (March), discharge was only $1.4 \%$. Therefore, the tidal actions dominated in the system, which subsequently turned to well mixed and the average energy required to mix the water column in the estuary was $33.8 \mathrm{~J} \mathrm{~m}^{-3}$.

During dry season, stratification parameter fluctuated from 0.5 to 0.8 (partially mixed) in neap phase, whereas for spring phase most of the observations over the tidal cycle showed stratification number varying from 0 to 0.1 (well mixed). During wet season, stratification parameter calculated from profiles during high tides showed values ranging from 1.3 to 1.9 . This was due to the temporary stratification developed due to salt wedge intrusion. Once freshwater conditions prevailed and as the saline layer was pushed out of 

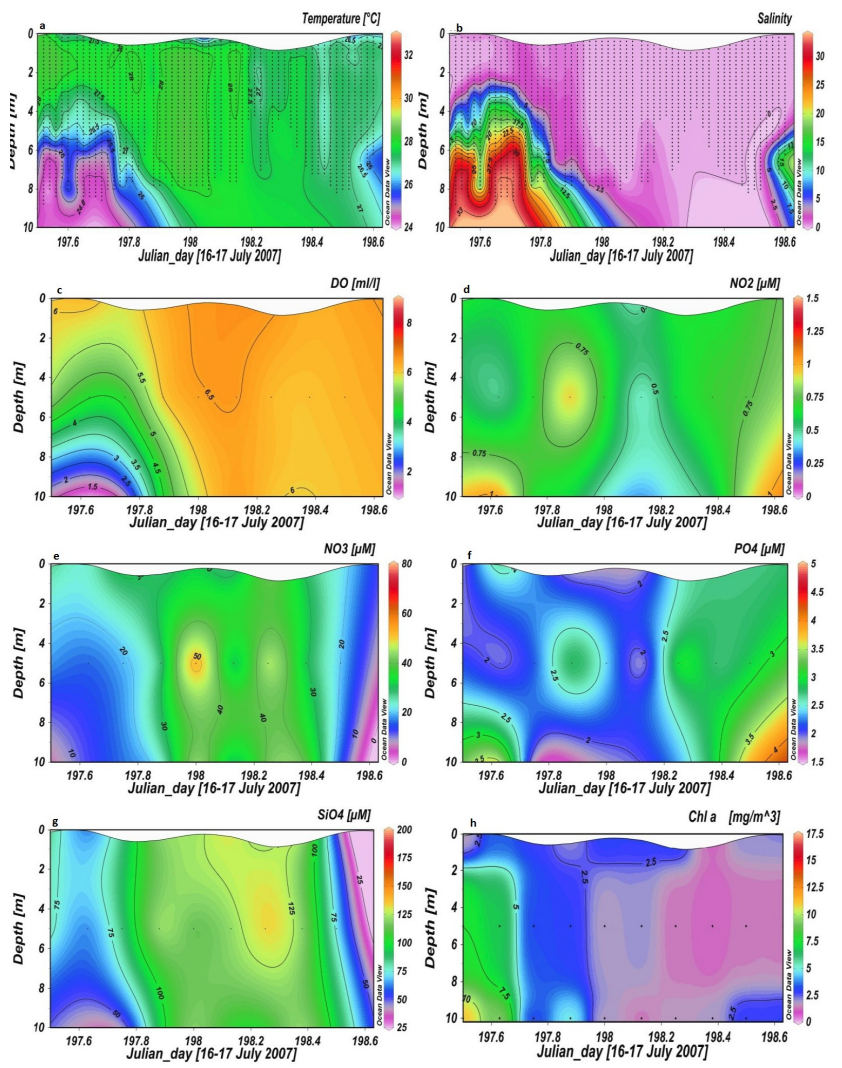

Fig. 6. Depth-time contours of salinity, temperature DO, chlorophyll $a, \mathrm{NO}_{2}, \mathrm{NO}_{3}, \mathrm{PO}_{4}^{3}, \mathrm{SiO}_{4}^{4}$ for every three hours from surface, mid-depth and bottom during spring tide of wet season.

the estuary, stratification number became almost zero. The stratification parameter varies depending on the phase of tide and freshwater discharge, indicating that Cochin estuary experiences a transition from partially mixed (neap) or well mixed (spring) in dry season to periodically stratified state during wet season.

\subsubsection{Dissolved oxygen and nutrients}

The distribution of chemical properties is shown in Figs. 4-7. During dry neap, the average surface DO value $\left(7.74+1.76 \mathrm{ml}^{-1}\right)$ was higher than bottom $\left(4.37+1.66 \mathrm{mll}^{-1}\right)$. In contrast, the average nutrient concentration (except for $\mathrm{PO}_{4}^{3-}$ ) was higher at the bottom than at the surface for neap phase during dry season: $\mathrm{NO}_{2}$ (surface $0.55+0.41 \mu \mathrm{M} ;$ bottom $1.55+0.21 \mu \mathrm{M}$ ), $\mathrm{NO}_{3}$ (surface $1.79+1.10 \mu \mathrm{M}$; bottom $4.10+0.50 \mu \mathrm{M}$ ), $\mathrm{PO}_{4}^{3-}$ (surface $0.88+0.30 \mu \mathrm{M}$; bottom $0.60+0.13 \mu \mathrm{M}$ ) and $\mathrm{SiO}_{4}$ (surface $12.02+2.69 \mu \mathrm{M}$; bottom $15.73+3.87 \mu \mathrm{M}$ ). Unlike neap, the water column property distributions were homogeneous over much of the tidal cycle in spring phase (Figs. 5c, $\mathrm{e}-\mathrm{h})$. During wet season, the incursion of hypoxic water $\left(<1.06 \mathrm{mll}^{-1}\right)$ through bottom layers (Figs. 6c, 7c) on flood tides was discernible during both spring and neap tidal
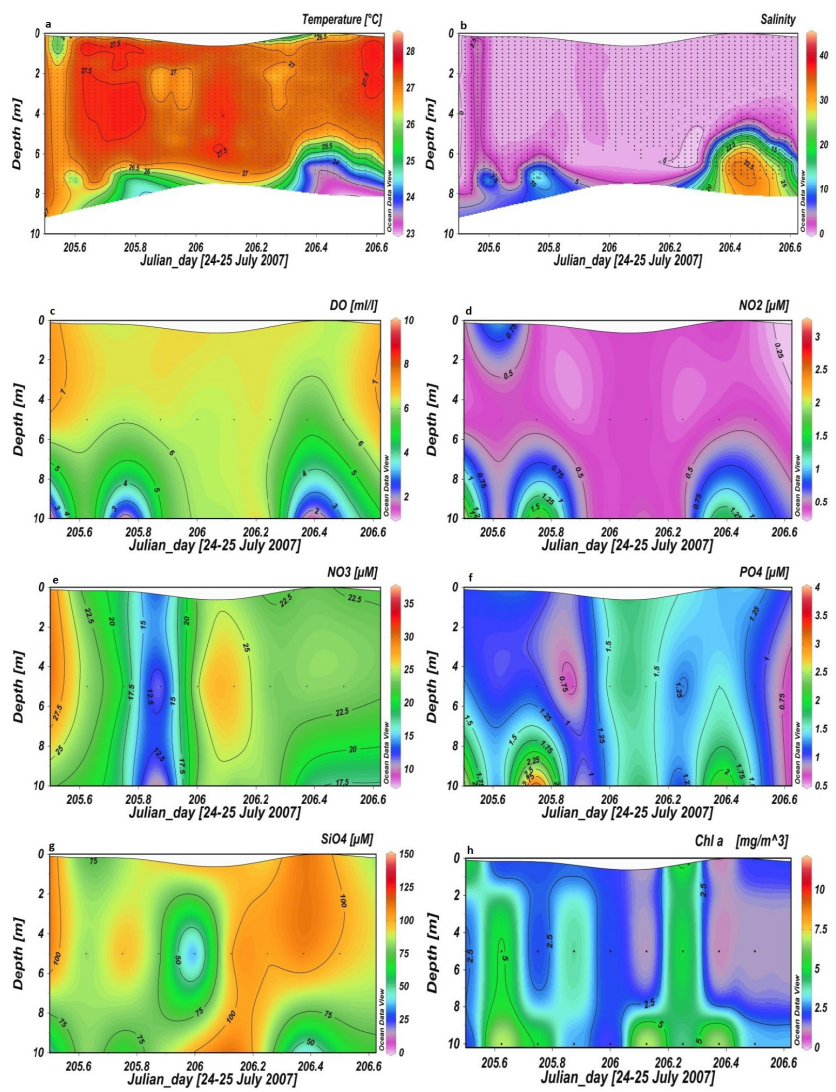

Fig. 7. Depth-time contours of salinity, temperature DO, chlorophyll $a, \mathrm{NO}_{2}, \mathrm{NO}_{3}, \mathrm{PO}_{4}^{3}, \mathrm{SiO}_{4}^{4}$ for every three hours from surface, mid-depth and bottom during neap tide of wet season.

phases. The near-bottom intruding water was characterised by high $\mathrm{NO}_{2}$ (spring, $1.02 \mu \mathrm{M}$; neap, $1.84 \mu \mathrm{M}$ ), $\mathrm{NO}_{3}$ (spring, $12.29 \mu \mathrm{M}$; neap, $17.5 \mu \mathrm{M}$ ), $\mathrm{PO}_{4}^{3-}$ (spring, $3.68 \mu \mathrm{M}$; neap, $3.24 \mu \mathrm{M}$ ) and low $\mathrm{SiO}_{4}$ (spring, $39.65 \mu \mathrm{M}$; neap $38.03 \mu \mathrm{M}$ ) values. However, elevated levels of silicate $(120.66 \mu \mathrm{M})$, which is a land-derived nutrient, were found at the surface. Silicate showed a negative relationship with salinity $\left(r^{2}=0.48, n=31\right)$ during wet season, indicating that freshwater runoff is the principal source of silicate inputs. This is substantiated by the higher silicate concentrations in wet than during the low-runoff surveys.

\subsubsection{Chlorophyll $a$}

The distribution of chlorophyll $a$ pigments, which is a reliable measure of phytoplankton biomass, is shown in Figs. 4-7. Seasonal variations in chlorophyll $a$ distribution were observed with relatively higher values in dry seasons (on an average $12 \mathrm{mg} \mathrm{m}^{-3}$ ). The chlorophyll $a$ concentration was higher at the surface with its peak (Figs. 4d, 5d) during $12: 00 \mathrm{~h}$ to $15: 00 \mathrm{~h}$ which may be attributed to the vertical migration of light-sensitive phytoplankton species to the surface. During dry season, the maximum surface 
(a) Salinity Section on July 18,2008

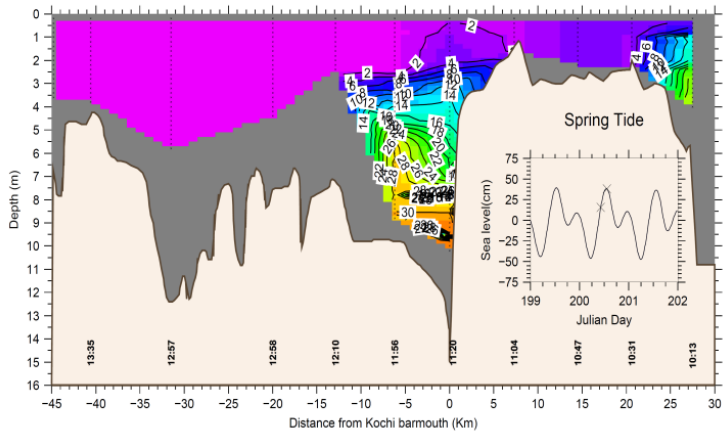

(c) Salinity Section on August 16, 2008

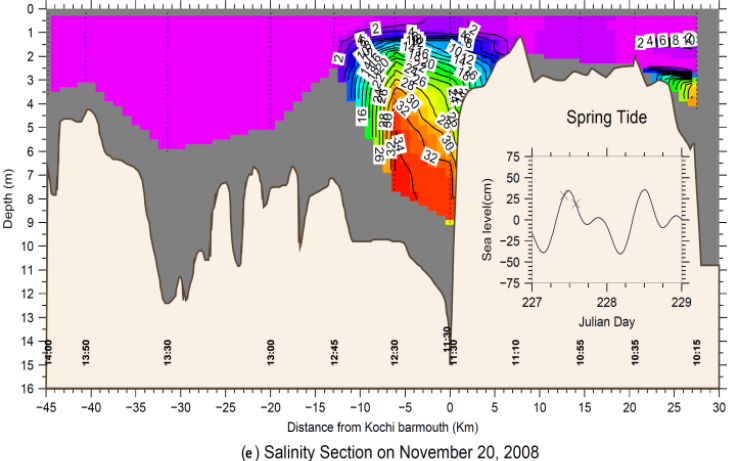

(e) Salinity Section on November 20, 2008

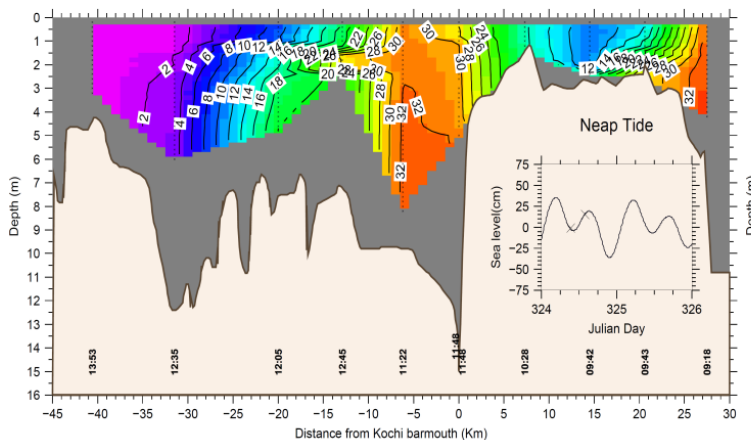

(g) Salinity Section on March 11, 2009

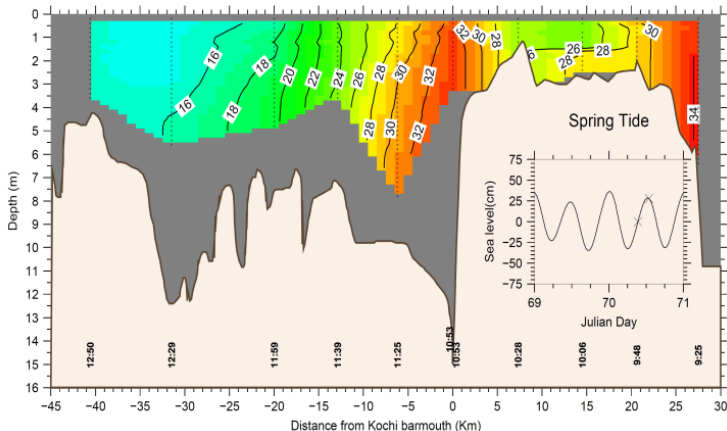

(b) Salinity Section on July 25, 2008

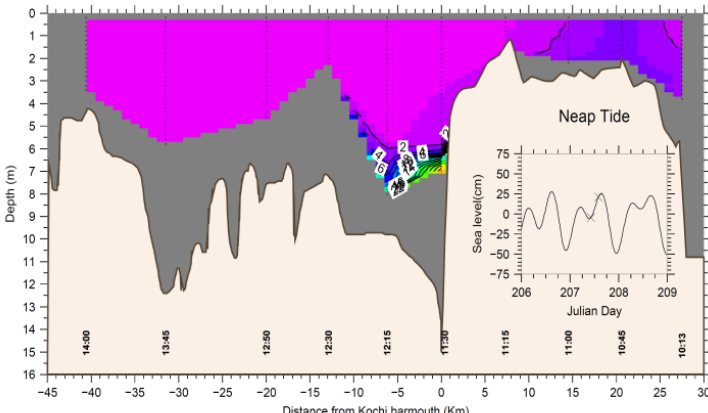

(d) Salinity Section on August 23, 2008
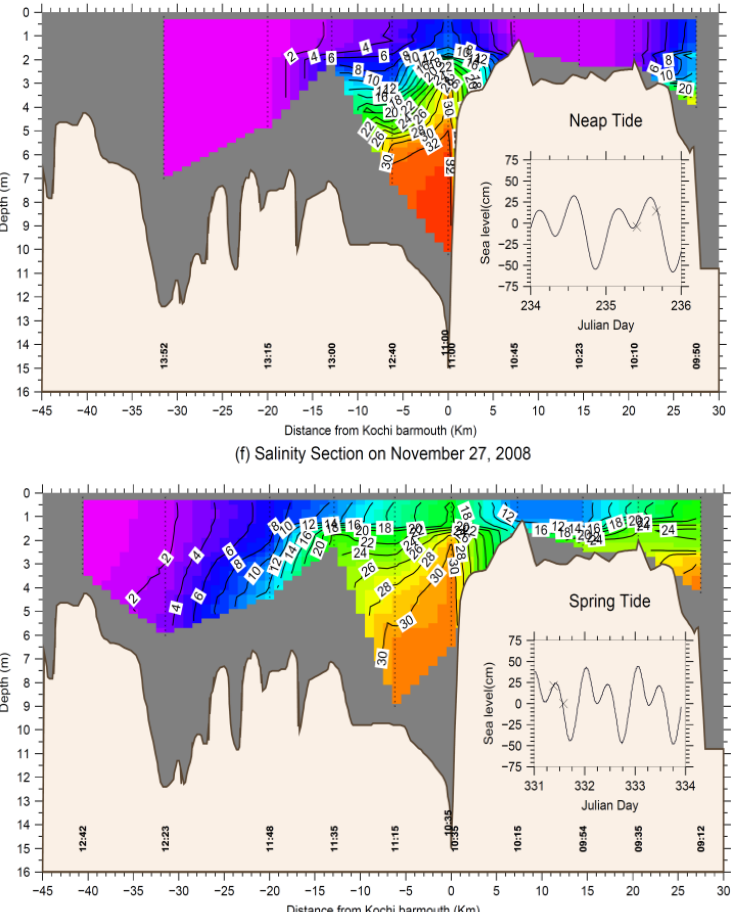

(h) Salinity Section on March 18, 2009

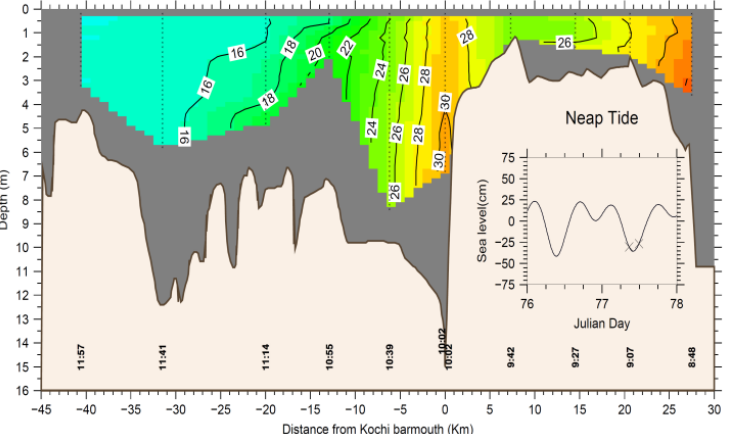

Fig. 8. Longitudinal synoptic distribution of salinity measured twice monthly (during spring and neap tides) During July 2008, August 2008, November 2008 and March 2009. The Cochin inlet is at the coordinate origin. The northern/southern arm stations are at positive /negative distances, respectively. The insets show the tidal amplitude and the times (as X's) when each survey began and ended. Times of each station appear along the lower $\mathrm{x}$-axis. 


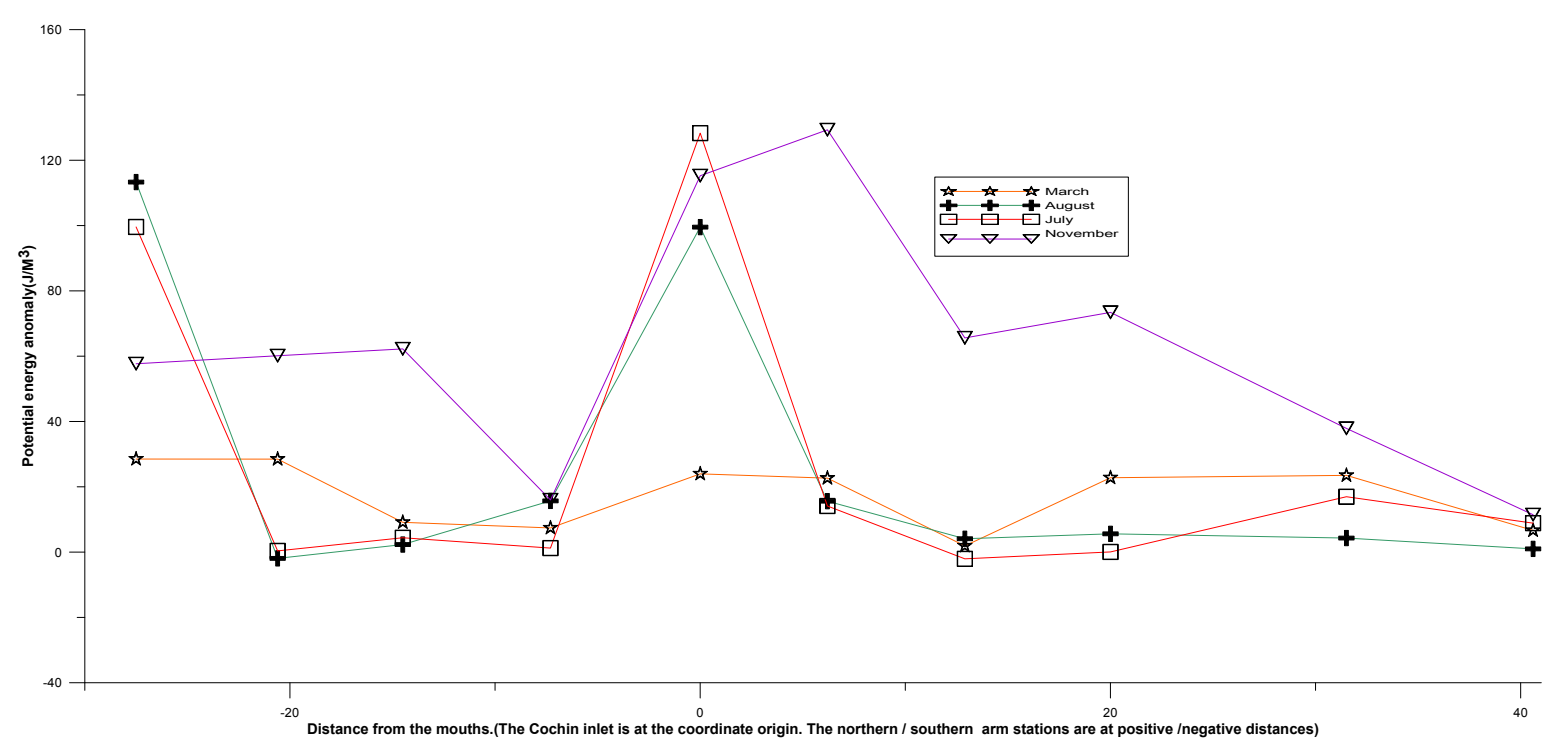

Fig. 9. Spatial variation in the potential energy anomaly (the months are characterised by southwest monsoon (July-August), northeast monsoon (November) and dry period (March)).

chlorophyll $a$ attained for neap and spring was $20.1 \mathrm{mg} \mathrm{m}^{-3}$ and $26.7 \mathrm{mg} \mathrm{m}^{-3}$, respectively. During salt wedge formation in both tidal phases of wet seasons (Figs. 6d, 7d), chlorophyll $a$ maxima layer was formed at the bottom ocean water [salinity 33.29; chl $a 11 \mathrm{mg} \mathrm{m}^{-3}$ (spring), salinity 33.04; chl $a 6.8 \mathrm{mg} \mathrm{m}^{-3}$ (neap)] and minimum layer at the surface freshwater [salinity 0.05 ; chl $a 1.1 \mathrm{mg} \mathrm{m}^{-3}$ (spring), salinity 0.01 ; chl $a 0.9 \mathrm{mg} \mathrm{m}^{-3}$ (neap)].

\subsection{Longitudinal salinity distributions (synoptic survey)}

The results of the salinity intrusion survey for the months July 2008, August 2008, November 2008 and March 2009 are shown in Fig. 8. These months are characterised by southwest monsoon, northeast monsoon and dry period, respectively.

In the year 2008, with the onset of monsoon on 31 May, the river discharge peaked with $8.7 \%$ of the total occurring in the month of June and flushing time calculated to be 5.8 days. The depth-averaged salinity of the southern arm stations $(8,9,10)$ and of the stations $(2,3,4)$ at the middle of northern arm presented low values averaging to 1.76-spring; 0.17-neap and 8.22-spring; 5.19-neap, respectively. Stations near the Cochin inlet $(5,6,7)$ exhibited high salinity unlike station 1 near the northern inlet with tidal amplitudes having some influence. Stations 1, 2 were prone to freshwater influence due to the Periyar River adjoining northern inlet, which is the major river contributing to the total discharge of the estuary. Overall, the freshening of the estuary was initiated by the monsoon.

By the end of June, the monsoon peaked and July experienced the maximum freshwater discharge amounting to $22.04 \%$ of the total and flushing time decreased to 2.8 days.
The salt wedge became prominent in July, transforming the status of the estuary to that of a salt wedge type (Fig. 8a, b). A weaker salt wedge front originating from northern inlet, which was visible only in spring phase of July, persisted in all other monsoon months. Hence, higher salinities (18-34) were restricted to the bottom waters of the stations adjacent to the inlets $(5,6,7$-Cochin inlet; 1, 2-northern inlet). All the other stations remained well mixed with depth averaged salinity reaching salinity values as low as 0.05 .

The salt intrusion length during both spring and neap tides of the synoptic survey has been defined as the length from the river mouth (Cochin inlet) along the river channel to the point where the bottom salinity is 2 PSU. On average, the intrusion length from the Cochin inlet to south averaged to $15 \mathrm{~km}$ and $11 \mathrm{~km}$ during spring and neap phases, respectively, of monsoon months. The results in August differed distinctly, with the intrusion greater in neap $(15 \mathrm{~km})$ than spring $(13 \mathrm{~km})$ since the neap observations were carried out during high tides whereas for spring they were during low tides (Fig. 8c, d). This entails the significance of the observation time with respect to tidal cycles denoting the relevance of time series measurements in the system. The depth of the interface (defined as the height of 2 PSU isohaline from the bottom) decreased gradually towards the outer end of the estuary. This depth, which is also the thickness of the bottom saline water layer, was greater in spring compared to neap phase at the mouth for the time series measurements (Figs. 6a, 7a), implying that saline intrusion was more during spring phase.

As the river discharge decreased from July to September (Fig. 2b), coincidently the salt wedge advected further upstream, suggesting an inverse relationship of salt intrusion with river flow. The withdrawal of monsoon concurred with the reduction in freshwater discharge. This resulted in the 
Table 1. Results of Pearson correlation analysis $(R)$ for the investigated physical and chemical variables during monthly observation.

\begin{tabular}{|c|c|c|c|c|c|c|c|c|c|c|}
\hline Parameters & Salinity & Temp & DO & $\mathrm{pH}$ & Nitrate & Nitrite & Ammonia & Silicate & Phosphate & Chl $a$ \\
\hline Salinity & 1 & & & & & & & & & \\
\hline Temp & 0.028 & 1 & & & & & & & & \\
\hline DO & $-0.370 * *$ & $0.375^{* *}$ & 1 & & & & & & & \\
\hline $\mathrm{pH}$ & $0.524 * *$ & $0.690^{* *}$ & $0.203 *$ & 1 & & & & & & \\
\hline Nitrate & $-0.308 * *$ & -0.027 & 0.173 & -0.122 & 1 & & & & & \\
\hline Nitrite & 0.106 & 0.059 & $-0.209 *$ & -0.017 & 0.139 & 1 & & & & \\
\hline Ammonia & -0.027 & 0.054 & -0.092 & 0.064 & -0.068 & $-0.204 *$ & 1 & & & \\
\hline Silicate & $-0.650 * *$ & 0.168 & $0.290 * *$ & $-0.231 *$ & $0.251 * *$ & $-0.186^{*}$ & $0.247 * *$ & 1 & & \\
\hline Phosphate & 0.117 & 0.117 & -0.127 & 0.168 & 0.125 & -0.027 & 0.055 & 0.032 & 1 & \\
\hline Chl $a$ & 0.086 & 0.158 & -0.038 & 0.16 & 0.014 & -0.038 & -0.048 & -0.029 & $0.455^{* *}$ & 1 \\
\hline
\end{tabular}

*: $P<0.051, * *: P<0.012$, bold values indicate negative correlation.

longitudinal dispersion of the salinity field. From $11.81 \%$ in October, the river discharge was reduced to $3.34 \%$ in December. Consequently, flushing time also increased from 3.5 days in October to 8.4 days in December. During the period, though the salinity at stations near Cochin inlet $(5,6,7)$ were invariably high over the vertical, there was a consistent increase in the salinity at all other stations. However, the uppermost station (10) remained far away from the influence of marine water irrespective of tidal phases. Later when the dry period (from January to April average discharge is only $1.4 \%$ of total) commenced, the tidal actions dominated in the system. The flushing time was 9.3 days in January, which increased to 13 days in April. The salinity field extended up to station 10 with maximum depth-averaged salinity (15.12) attained in spring phase of March. In May, there was a slight increase in discharge to $2.5 \%$ of the yearly discharge and the flushing time was 14.7 days. The aftermath of an anomalous rainfall in the catchment of Periyar during our spring observation caused station 1 at the northern inlet to be freshwater dominated.

\subsection{Statistical analysis of monthly observation}

The Pearson correlations between the surface values of ecologically important variables are shown in Table 1. Salinity showed significant positive correlation with $P^{\mathrm{H}}(R=$ $-0.524, P<0.01)$. Relevantly, it was negatively correlated with nitrate $(R=-0.308, P<0.01)$, DO $(R=-0.370$, $P<0.01)$ and silicate $(R=-0.650, P<0.01)$, indicating freshwater as their source of inputs. Chlorophyll $a$ was highly correlated with phosphate $(R=0.455, P<0.01)$, with no significant correlation with salinity. Also, there was no distinct correlation between salinity and phosphate. Although DO was inversely correlated with chlorophyll $a$, it was not significant, indicating that biological processes are not the only factor influencing DO in the estuary. Negative correlations between salinity and DO were highly significant $(R=-0.370, P<0.001)$.
The two-way analysis of variance carried out on monthly samples is shown in Table 2. Salinity variations were found to be significant spatially $(F=7.88, P<0.001)$ and temporarily $(F=6.37, P<0.001)$. However, temperature varied more temporarily $(F=2.29, P<0.01)$ than spatially $(F=0.88, P<0.01)$ owing to the seasonal changes in the domain. Among the different nutrient species, only phosphate manifested fluctuations spatially $(F=9.87, P<$ $0.001)$ and temporarily $(F=2.66, P<0.005)$. Chlorophyll $a$ marked remarkably more significant variations spatially $(F=4.35, P<0.001)$ than temporarily $(F=1.23$, $P<0.5)$.

\section{Discussions and summary}

Temperature has lesser influence in density stratification than salinity because the salinity range is larger than temperature in estuaries (Dyer, 1973). Thus, an attempt was made to analyze the variations in stratification considering salinity as the major determining factor. The data presented from this survey suggests that salinity fluctuates at different timescales, including intratidal, fortnightly of spring and neap tidal cycle, and seasonal wet and dry periods. It is evident from our study that Cochin estuary experiences a transition from partially mixed (neap) or well mixed (spring) in dry season to periodically stratified state during monsoon. The potential energy anomaly (PEA) increases with increasing river discharges, specifically to the inlet regions in the southwest monsoon and northeast monsoon periods.

The Arabian Sea, one of the major upwelling zones of the world, experiences upwelling from June to October (Banse, 1968; Naqvi et al., 2000). Srinivas and Dinesh Kumar (2006) claim that the increased intensity of upwelling processes in Cochin in July is instrumental in generating a drop in sea level and surface temperature. Whilst this process aids in quicker flushing of the estuarine water through the bar mouth (Udaya Varma, 1981), low tidal amplitudes and increasing number of oscillations in the southwest coast may lead to 
Table 2. Two-way analysis of variance for differences of ecologically important parameters on sampling stations and sampling months for the survey (June 2008 to May 2009). $F$ indicates the likelihood ratio; $P$ indicates the probability.

\begin{tabular}{lrrrr}
\hline Variables & \multicolumn{2}{c}{ Station } & \multicolumn{2}{c}{ Year } \\
\hline & $F$ & $P$ & $F$ & $P$ \\
\hline Salnity & 7.883679 & $0.000065^{* * *}$ & 6.370352 & $0.00047 * *$ \\
Temperature & 0.884074 & 0.541915 & 2.291627 & 0.014651 \\
DO & 3.411882 & $0.000984 * *$ & 2.104926 & 0.025726 \\
pH & 3.836676 & $0.000301 * *$ & 3.082916 & $0.001237 *$ \\
Nitrate & 0.419885 & 0.922091 & 12.94469 & $0.00002 * * *$ \\
Nitrite & 0.971728 & 0.4674 & 9.793611 & $0.00042 * *$ \\
Ammonia & 1.006034 & 0.439704 & 8.134114 & $0.00032 * *$ \\
Silicate & 1.843739 & 0.068204 & 7.809754 & $0.00008 * * *$ \\
Phosphate & 9.872694 & $0.0005 * *$ & 2.662658 & $0.004654 *$ \\
Chl $a$ & 4.357485 & $0.00007 * * *$ & 1.233476 & 0.273961 \\
\hline
\end{tabular}

*** Indicates statistically significant differences $<0.0001, * *$ indicates $<0.001$ and $*$ indicates $<0.01$.

small inter-tidal expanses, which reduce flushing (Qasim, 2003). Coastal upwelling in the Arabian Sea induces anomalies in the distribution of physiochemical properties characterised by a rapid decrease in temperature and DO concomitant with an increase in salinity and surface nutrients, particularly nitrates (Rotchord, 1975) that could foster enhanced primary productivity of the area (Mann and Lazier, 1996).The upwelled water area is situated just off the shelf break (Shetye et al., 1990), where the predominant tidal circulation is responsible in advecting these waters into the estuaries. Significantly, the intruding water mass at the bottom layers during monsoon season was identified as upwelled water from the adjacent shelf with its peculiar characteristics of low temperature, high salinity, severe oxygen depletion, nutrient rich and high chlorophyll $a$.

The salt wedge plays an important role in the distribution of chemical and biological variables that have profound impacts on water quality (Haralambiduo et al., 2010). Coastal hypoxia (defined here as $<1.42 \mathrm{ml}$ ) develops seasonally in many estuaries, fjords, and along open coasts as a result of natural upwelling (Levin et al., 2009). The upwelled water incursion and the stratification induced by freshwater discharge of monsoon season fueled the oxygen depletion at the bottom layer. Under persistent stratification, the probability of the shift of hypoxic to anoxic condition in the intruding frontal system cannot be ruled out. Our detailed hydrological analysis suggests that the dynamic and energetic environment of Cochin estuary hindered the sustainability of this front at the bottom. The onset of strong ebb phase and high flushing of monsoon flushed the estuary from top to bottom with well oxygenated waters by pushing the saline wedge seaward. The duration of the existence of this front in our system was greatly determined by the tidal range and duration of flood-ebb cycles. The dependence of the salt wedge advancement on tidal range was clearly identifiable in spring phase as the tidal amplitude of $26.05 \mathrm{~cm}$ was not sufficient to force the transient stratified flow. The diurnal inequality of the neap phase contributed well to the flushing period $(12 \mathrm{~h})$ as when compared with the semidiurnal spring phase ( $9 \mathrm{~h} 30 \mathrm{~min})$. The time-dependent nature of salt wedge has also been justified in Fraser estuary (Geyer and David, 1989), where during ebb the saline structure was eroded due to local enhancement of shear instability. Therefore, the periodic advance and retreat of the salinity wedge front is inevitable in preserving the ecosystem functioning and maintaining the health of the estuary.

The Cochin estuary is reported to be an eutrophic estuary (Qasim, 2003). During high runoff surveys, an increase in the overall nutrient concentrations was noticed when compared to low runoff surveys. However, the salt wedge intrusion affected its distributions in the water column. Higher concentrations of phosphate and nitrite were restricted to the near bottom saline intrusions, but extreme levels of silicate and nitrate were observed in low salinities. Although the near-bottom seawater intruded with high nutrients, freshwater runoff was the principal source of silicate and nitrate supply. This is further substantiated by the statistical results, which revealed that silicate and nitrate were highly negatively correlated with surface salinity whereas phosphate and nitrite did not manifest a significant relationship. As the river flow weakened after monsoon, the flushing of the estuary diminished and the nitrite, nitrate, ammonia, phosphate and silicate loadings through anthropogenic activities (industries) and sediment re-suspension alter the nutrient stoichiometry substantially (Martin et al., 2008). Phosphorous showed both seasonal and spatial variability. The surface phosphate concentrations were moderately high in the stations with high salinity whereas concentrations decreased in low saline regions. The previous work on the fractionation of phosphorous in the Cochin estuary (Balchand and Nair, 1994) also concluded that enhanced amounts of exchangeable $P$ 
appeared in high saline waters, signifying the presence of biologically available nutrient phosphorus.

In the Cochin estuary, nutrients are not a limiting factor for the optimum phytoplankton growth at any time of the year (Balachandran et al., 2005); also, transient variations in the water quality play a significant role on phytoplankton behaviour (Madhu et al., 2010). Prior experimental studies had found that generally Cochin estuary exhibits high chlorophyll $a$ when intermediate salinity (10-25) conditions prevail (Qasim and Sankaranarayanan et al., 1972). Our study substantiated the above statements such that increased chlorophyll $a$ distribution was observed during dry season compared to wet season. The increased flushing during monsoon resulted in low chlorophyll concentration in surface layers where salinity was low. The effect of river discharge and surface salinity on the surface chlorophyll $a$ distribution is clearly depicted in Fig. 2b, such that the maximum chlorophyll concentrations were observed during lean-river flow months when the surface salinity was high. High riverine discharge leads to reduced residence time, leading to increased flushing of phytoplankton biomass out of the estuary (Lane et al., 2007). Further, the overall surface distribution of chlorophyll $a$ during monsoon was affected when the increased river discharge restricted the salinity dispersion and hence the saline waters with biologically available phosphorous was limited in some areas along the estuary. Phosphorous is being attributed as a limiting nutrient in freshwater-dominated systems (Neil, 2005). The river pulses impede the salinity field expansion affecting the nutrient distributions. However, salinity could not be considered as the only determining factor for triggering phytoplankton growth. Unravelling these evidences is henceforth a major task to be accomplished through sustained research. Although the linking between temporal stratification of the water column with chlorophyll $a$ distributions is a question of some subtlety, this study reveals the persuasive evidence of its critical importance in the Cochin estuary.

The advancement in our understanding of time-dependent nature of water column stabilization and destabilization mechanisms can be achieved through continuous monitoring of multiple stations along with supporting flow field to define various processes in spatial and time scales.

Acknowledgements. This study forms a part of project "Ecosystem modeling of Cochin estuary" funded by Integrated Coastal and Marine Area Management (ICMAM). We are indebted to the project staff in the small dinghies, who had overcome the adverse weather conditions for sample collection. We thank the Director of NIO-Goa, Scientist In-charge, NIO-Regional Centre, Cochin, for the support and encouragement provided towards the completion of this work. Shivaprasad Amaravayal is also grateful to CSIR, New Delhi, for financial support in the form of Senior Research fellowship. This is NIO contribution no. 5307.

Edited by: A. D. Reeves

\section{References}

Balachandran, K. K., Laluraj, C. M., Nair, M., Joseph, T., Sheeba, P., and Venugopal, P.: Heavy metal deposition in a flowrestricted, tropical estuary, Estuar Coast Shelf Sci., 65, 361-370, 2005.

Balachandran, K. K., Reddy, G. S., Revichandran, C., Srinivas, K., Vijayan, P. R., and Thottam, T. J.: Modelling of tidal hydrodynamics for a tropical ecosystem with implications for pollutant dispersion (Cochin Estuary, Southwest India), Ocean Dynam., 58, 259-273, 2008.

Balchand, A. N. and Nair, S. M.: Fractionation of phosphorous in the sediments of a tropical estuary, Environ Geol., 23, 284-294, 1994.

Banse, K.: Hydrography of the Arabian Sea shelf of India and Pakistan and effects on demersal fishes, Deep Sea Res., 15, 45-79, 1968.

Blanton, J.: Energy dissipation in a tidal estuary, J. Geophys. Res., 74, 5460-5466, 1969.

Brenkert, A. and Malone, E.: Vulnerability and resilience of India and Indian states to climate change: a first-order approximation, Joint Global Change Research Institute, 65, 2003.

Dinesh Kumar, P. K., Sankaranarayanan, V. N., and Saraladevi, K. An introduction to the system, prior studies, historical trends and future implications, Indian J. Environ. Protection., 14, 98-102, 1994.

Dyer, K. R.: Estuaries: A Physical introduction, Wiley-Interscience, London, 1, 1973.

Dyer, K. R.: Estuaries: A Physical introduction, 2nd Edn., John Wiley and Sons, Sydney, 1997.

Geyer, W. R. and David, M. F.: Tide-Induced Variation of the Dynamics of a Salt Wedge Estuary, J. Phys. Oceanogr., 19, 1060$1072,1989$.

Government of Kerala, General features, http://en.wikipedia.org/ wiki/Kerala, 2005b.

Grasshoff, K., Ehrhardt, M., and Kremling, K.: Methods of Seawater Analysis, Verlag Chemie, Weinheim, 419, 1983.

Haralambidou, K., Sylaios, G., and Tsihrintzis, V. A.: Salt-Wedge propagation in Mediterranean micro-tidal river mouth, Estuar. Coast Shelf Sci., 90, 174-184, 2010.

Joseph, S. and Ouseph, P. P.: Assessment of nutrients using multivariate statistical techniques in estuarine systems and its management implications: a case study from Cochin Estuary, India, Water Environ J., 24, 126-132, 2010.

Kasai, A., Kurikawa, Y., Ueno, M., Rober, D., and Yamashita, Y.: Salt-wedge intrusion of seawater and its implication for phytoplankton dynamics in the Yura Estuary, Japan., Estuar. Coast Shelf Sci., 86, 408-414, 2010.

Ketchum, B. H.: Estuaries and enclosed seas, Elsevier science publication Comp, Amsterdam, 1-14, 1983.

Krishnakumar, K. N., Prasada Rao, G. S. L. H. V., and Gopakumar, C. S.: Rainfall trends in twentieth century over Kerala, India, Atmos Environ., 43, 1940-1944, 2009.

Lane, R., Day, J., Marx, B. D., Reyes, E., Hyfield, E., and Day, J. N.: The effects of riverine discharge on temperature, salinity, suspended sediment and chlorophyll $a$ in a Mississippi delta estuary measured using a flow-through system, Estuar. Coast Shelf Sci., 74, 145-154, 2007.

Levin, L. A., Ekau, W., Gooday, A. J., Jorissen, F., Middelburg, J. J., Naqvi, S. W. A., Neira, C., Rabalais, N. N., and Zhang, J.: Effects 
of natural and human-induced hypoxia on coastal benthos, Biogeosciences, 6, 2063-2098, doi:10.5194/bg-6-2063-2009, 2009.

Lund-Hansen, L. C., Skyum, P., and Christiansen, C Modes of stratification in a semi-enclosed bay at the North Sea-Baltic Sea transition, Estuar. Coast Shelf Sci., 42, 45-54, 1996.

Madhu, N. V., Balachandran, K. K., Martin, G. D., Jyothibabu, R., Thottathil, S. D., Nair, M, Joseph, T., and Kusum, K. K.: Short Term Variability of Water Quality and its Implications on Phytoplankton Production in a Tropical Estuary (Cochin Estuary - India), Environ. Monit. Asses., 170, 287-300, doi:10.1007/s10661009-1232-y, 2010.

Mann, K. H. and Lazier, J. R. N.: Vertical structure of the open ocean: Biology of the mixed layer, Dynamics of marine ecosystems-Biological-physical interactions in the oceans, 2nd Blackwell, Science, 12, 56-97, 1996.

Menon, N. N., Balchand, A. N., and Menon, N. R.: Hydrobiology of the Cochin estuary system a review, Hydrobiologia, 43, 149-183, 2000.

Martin, G. D., Vijay, V. J., Laluraj, C. M., Madhu, N. V., Joseph, T., Nair, M., Gupta, G. V. M., and Balachandran, K. K.: Fresh water influence on nutrient stoichiometry in a tropical estuary, south west coast of India, Appl. Ecol. Environ. Res., 6, 57-64, 2008.

Naqvi, S. W. A., Jayakumar, D. A., Narvekar, P. V., Naik, H., Sarma, V. S., D'Souza, W., Joseph, T., and George, M. D.: Increased marine production of $\mathrm{N}_{2} \mathrm{O}$ due to intensifying anoxia on the Indian continental shelf, Nature, 408, 346-349, 2000.

Neil, M.: A method to determine which nutrient is limiting for plant growth in estuarine waters at any salinity, Marine Pollut. Bull., 50, 945-955, 2005.

Nepf, H. M. and Geyer, W. R.: Intratidal variations in stratification and mixing in the Hudson estuary, J. Geophys. Res., 101, 1207912086, 1996.

Nunes Vaz, R. A., Lennon, G. W., and De Silva Samarasinghe, J. R.: The negative role of turbulence in estuarine mass transport, Estuar. Coast Shelf Sci., 28, 361-377, 1989.

Qasim, S. Z.: Indian Estuaries. Allied Publication Pvt. Ltd., Heriedia Marg, Ballard estate, Mumbai, 259 pp., 2003.

Qasim, S. Z. and Gopinathan, C. K.: Tidal cycles and the environmental features of Cochin backwater (A tropical estuary), proceedings of the Indian academy of sciences, Bangalore, 1969.
Qasim, S. Z. and Sankaranarayanan, V. N.: Organic Detritus of a Tropical Estuary, Mar. Biol., 15, 193-199, 1972.

Ranasinghe, R. and Pattiaratchi. C.: Circulation and mixing characteristics of a seasonally open tidal inlet: a field study, Aust. J. Mar. Freshwater Res., 50, 281-290, 1999.

Rippeth, T. P. and Simpson, J. H.: The frequency and duration of episodes of complete vertical mixing in the Clyde Sea, Cont. Shelf Res., 16, 933-947, 1996.

Rotchord, D. J.: Nutrient environment of Australian coastal waters, Aust. J. Mar. Freshwater Res., 26, 223-243, 1975.

Shetye, S. R., Gouveia, A., Shenoi, S. S. C., Sundar, D., Michael, G. S., Almeida, A. M., and Shatanam, K.: Hydrography and circulation off the west coast of India during the Southwest monsoon, J. Mar. Res., 48, 359-378, 1990.

Simpson, J. H.: The shelf - sea fronts: implications of their existence and behaviour, Phil. T. Roy. Soc. Lon. A, 302, 531-546, 1981.

Srinivas, K. and Dinesh Kumar, P. K.: Atmospheric forcing on the seasonal variability of sea level at Cochin, southwest coast of India, Cont. Shelf Res., 26, 1113-113, 2006.

Srinivas, K., Revichandran, C., Thottam, T. J., Maheswaran, P. A., Asharaf, M., and Murukesh, N.: Currents in the Cochin estuarine system during March 2000 (Southwest coast of India), Indian J. Mar. Sci., 32, 123-132, 2003a.

Srinivas, K., Revichandran, C., Maheswaran, P, A., Asharaf, M., and Murukesh N.: Propagation of tides in the Cochin estuarine system, Southwest coast of India, Indian J. Mar. Sci., 32, 14-24, $2003 b$.

Strickland, J. D. H. and Parsons, T. R.: In: A Practical Handbook of Seawater Analysis. Bulletin of Fisheries Research Board, Canada, 2, 167-310, 1972.

Udaya Varma, P., Pylee, A., and Rama Raju, V. S.: Tidal influence on the seasonal variation in current and salinity around Willington Island, Mahasagar, 4, 225-237, 1981.

Uncles, R. J., Ong, J. E., and Gong, W. K.: Observations and Analysis of a stratification-destratification event in a tropical estuary, Estuar. Coast Shelf Sci., 31, 651-665, 1990. 